Research Paper

\title{
Implementation of PT. Asia Forestama Raya's CSR for Community Economic Empowerment during the Covid-19 Pandemic
}

\author{
Fahrial $^{1}$, Andrew Shandy Utama ${ }^{2}$ \\ ${ }^{1}$ Faculty of Agriculture, Universitas Islam Riau, Indonesia. \\ ${ }^{2}$ Faculty of Law, Universitas Lancang Kuning, Indonesia.
}

Article History

Received:

20.02.2021

Revised:

05.03.2021

Accepted:

10.03.2021

*Corresponding Author:

Andrew Shandy Utama

Email:

andrew.fh.unilak@gmail.com

This is an open access article, licensed under: $\mathrm{CC}-\mathrm{BY}-\mathrm{SA}$

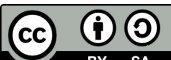

Abstract: PT Asia Forestama Raya is a forest product processing factory for the wood industry's raw materials. Based on Article 74 Paragraph (1) of Law Number 40 of 2007 concerning Limited Liability Companies, it is stipulated that companies that carry out their business activities in the natural resources sector and / or fields related to natural resources are required to implement CSR. In Article 10 of Riau Provincial Regulation Number 6 of 2012 concerning Corporate Social Responsibility in Riau Province, it is stated that CSR programs can take the form of community economic empowerment. This research aims to explain the implementation of PT Asia Forestama Raya's CSR on community economic empowerment during the Covid-19 pandemic. The method used in this research is socio-legal research. During the Covid-19 pandemic, the public really expected a real contribution from PT Asia Forestama Raya. PT Asia Forestama Raya's obstacle in implementing community economic empowerment in Limbungan Village is that the financial condition of PT Asia Forestama Raya is currently in an unstable state. Efforts that can be made by the people of Limbungan Village if PT Asia Forestama Raya doesn't carry out a CSR program are to convey their aspirations to Commission IV of DPRD Pekanbaru City. Based on Article 32 of Riau Provincial Regulation Number 6 of 2012 concerning Corporate Social Responsibility in Riau Province, it is stated that if PT Asia Forestama Raya doesn't carry out CSR towards empowering the community's economy, the company can be subject to administrative sanctions by the Pekanbaru City Government.

Keywords: Community Economy, CSR, Covid-19. 


\section{Introduction}

In general, the principles that apply in business activities cann't actually be separated from our lives as humans. These principles are closely related to the value system adopted by society. The principles in business ethics include the principle of honesty, the principle of doing good and not doing evil, and the principle of justice [1].

From a business law perspective, there are two responsibilities that must be applied in business ethics, namely legal responsibility and social responsibility to society [2].

Social responsibility is basically a derivation of business ethics that arises from the existence of business interactions between people that complement each other's needs as a result of the infinite complexity of human needs [3]. Business ethics can bridge the interests between the company and the community, both people who are directly or indirectly affected by the company's operations.

Based on Article 74 Paragraph (1) of Law Number 40 of 2007 concerning Limited Liability Companies, it is stipulated that companies carrying out their business activities in the natural resources sector and / or fields related to natural resources are obliged to carry out social and environmental responsibility [4]. This provision aims to create a balanced relationship between the company and the community [5].

In Indonesia, the term corporate social responsibility is better known as CSR. The issuance of Regional Regulation of Riau Province Number 6 of 2012 concerning Corporate Social Responsibility in Riau Province further strengthens the legal basis for implementing CSR for companies operating in the Riau Province [6]. In Article 10 of Riau Province Regional Regulation Number 6 of 2012 concerning Corporate Social Responsibility in Riau Province, it is stated that CSR programs can take the form of community empowerment and / or partnerships and environmental development and / or investment and / or donations / donations, and / or promotion.

Furthermore, Article 11 of the regional regulation also states that the work sector of CSR can be carried out at:

1. Education Sector

CSR programs in education can be programmed in the form of educational assistance and educational support facilities provided in the form of funds and / or goods and / or services to increase public intelligence.

2. Health Sector

CSR programs in the health sector can be programmed in the form of health service assistance, health support facilities, and increased health resources provided in the form of funds and / or goods to improve public health.

3. Infrastructure Sector

CSR programs in the infrastructure sector can be programmed in the form of building and repairing basic infrastructure for the public interest such as roads, bridges and irrigation to meet community needs.

4. Sport and Cultural Arts Sector

CSR programs in the fields of sports and cultural arts can be programmed in the form of sports facilities and cultural arts assistance provided in the form of funds and / or goods and / or facilities to support community activities.

5. Social and Religious Sector

CSR programs in the social and religious fields can be programmed in the form of service assistance and / or facilities provided in the form of funds and / or goods and / or facilities to improve community welfare and religious quality.

6. Environmental Preservation Sector

CSR programs in the field of environmental preservation can be programmed in the form of efforts to protect the environment to improve environmental sustainability.

7. Social Economy Business Sector

CSR programs in the social economy sector can be programmed in the form of assistance provided in the form of funds and / or goods to foster and empower the community's economy in accordance with regional characteristics and potential.

8. Empowerment of Indigenous Peoples Sector 
CSR programs in the field of empowerment of indigenous peoples can be programmed in the form of assistance provided in the form of funds and / or goods and / or services to maintain the existence of indigenous peoples and empower their economy.

In the last few months the spread of the Covid-19 outbreak in Pekanbaru City has continued to increase from time to time [7]. The policy of the Pekanbaru City Government to close crowded centers and impose Large-Scale Social Restrictions to Micro-Scale Social Restrictions in several subdistricts to prevent the spread of the Covid-19 outbreak has had a major impact on the economy of the community, including the people of Limbungan Village. The public certainly hopes for a real contribution from PT Asia Forestama Raya in the midst of the Covid-19 pandemic.

From observations of research conducted in Limbungan Village, researchers obtained information from the public that the CSR program of PT Asia Forestama Raya was very minimal felt by the community, especially in terms of empowering the community's economy.

CSR is an obligation that must be carried out by every company in order to create a good relationship between the company and the community, especially the people who live around the company [8].

Based on the background of the problems described above, the problems discussed in this research are how the implementation of PT Asia Forestama Raya's CSR towards empowering the community's economy during the Covid-19 pandemic?

\section{Method of Research}

Legal research is a scientific activity based on methods, systematics, and certain thoughts that aim to study one or more specific legal phenomena by analyzing them [9]. The method used in this research is socio-legal research. Socio-legal research is a research conducted by explaining the implementation of laws and regulations on problems that exist in society. Sources of data used in this research are primary data and secondary data. Primary data, namely data obtained directly from the results of observations, interviews, and questionnaires at the research location; while secondary data is data obtained from scientific journals, legal literature, and statutory regulations. The data collection techniques used in this research were observation, interviews, questionnaires, and literature study. The data analysis technique used in this research is qualitative analysis.

\section{Discussion}

In 2007, there were significant changes regarding CSR in Indonesia after the enactment of Law Number 25 of 2007 concerning Investment and Law Number 40 of 2007 concerning Limited Liability Companies [10].

The passing of Law Number 25 of 2007 concerning Investment is the legal basis for implementing CSR in Indonesia. The provisions regarding CSR are strictly regulated in Article 15 Letter b of Law Number 25 of 2007 concerning Investment, which states that every investor is obliged to carry out CSR. Based on Law Number 25 of 2007 concerning Investment, it is explained that CSR is the responsibility inherent in every investment company to continue to create harmonious, balanced relationships and in accordance with the environment, values, norms and culture of the local community.

In line with that, the passing of Law Number 40 of 2007 concerning Limited Liability Companies complements the legal basis for implementing CSR in Indonesia. The provisions regarding CSR are strictly regulated in Article 74 Paragraph (1) of Law Number 40 of 2007 concerning Limited Liability Companies, which confirms that companies that carry out their business activities in the field of natural resources and / or fields related to natural resources are required to implement CSR. Based on Law Number 40 of 2007 concerning Limited Liability Companies, it is explained that CSR is a company's commitment to participate in sustainable economic development in order to improve the quality of life and the environment that is beneficial, both for the company itself, the local community, and society in general.

PT Asia Forestama Raya is a forest product processing factory for the wood industry's raw materials [11]. PT Asia Forestama Raya began operating in Pekanbaru City since 1986 under the name PT Rantau Jaya Sakti, which is domiciled in Limbungan Village. Initially, the company stood on an empty land in the form of a forest on the banks of the Siak River on the edge of Pekanbaru City. 
However, along with the development and progress of Pekanbaru City as the capital of Riau Province, currently Limbungan Village has turned into a densely populated area.

From observations of research conducted in Limbungan Village, researchers obtained information from the public that the CSR program of PT Asia Forestama Raya was very minimal felt by the community, especially in terms of empowering the community's economy. In 2017, PT Riau Crumb Rubber Factory also didn't carry out CSR to the community in Rumbai District, but there was no strict sanction from the Pekanbaru City Government to the company [12].

PT Asia Forestama Raya has actually implemented CSR towards empowering the community's economy. In 2008, PT Asia Forestama Raya provided a plot of land located in Limbungan Village for the creation of a traditional market managed by the community and this market still exists today [13].

The Integrated Farming System Program and the UMKM Program as one of the CSRs of PT Riau Andalan Pulp and Paper have a positive impact on improving the economy of the people of Pelalawan Regency [14]. The success of an area in improving the welfare of its people can be realized if all components of society are involved, including real participation from companies operating in the area [15].

In the last few months the spread of the Covid-19 outbreak in Pekanbaru City has continued to increase from time to time. The policy of the Pekanbaru City Government to close crowded centers and impose Large-Scale Social Restrictions to Micro-Scale Social Restrictions in several sub-districts to prevent the spread of the Covid-19 outbreak has had a major impact on the economy of the community, including the people of Limbungan Village. The public certainly hopes for a real contribution from PT Asia Forestama Raya in the midst of the Covid-19 pandemic.

In September 2020, Riau Province was included in the category of the top 10 (ten) areas most exposed to Covid-19. The Covid-19 pandemic that hit Riau Province had an impact on the economy of the community, including the people of Palas Village. Apart from expecting financial assistance from the government, one of the opportunities that the Palas Village community can take advantage of to build the village economy is to take advantage of the CSR programs of companies operating in Pelalawan Regency, both private companies and State-Owned Enterprises and Owned Enterprises. Regional [16].

The company has a strategic role in encouraging the growth of people's welfare. This is done by creating jobs and providing assistance to the state and society through the CSR program. Therefore, Law Number 40 of 2007 concerning Limited Liability Companies requires every company to implement CSR.

There are five steps that can be used as a guide for companies in formulating CSR programs, namely as follows:

1. Engagement, namely the approach taken by the company to the community to establish good communication and relationships.

2. Assessment, namely identification of problems that exist in society as well as national and international policies as material in the formulation of a CSR program.

3. Plan of action, namely the formulation of a CSR program plan that will be carried out by the company to suit the needs of the community and in line with the company's vision and mission.

4. Action and facilitation, namely the implementation of mutually agreed upon CSR programs, either directly carried out by the company or by the government and the community.

5. Evaluation and termination or reformation, namely the assessment conducted by the company on the successful implementation of the CSR program.

The obstacle in implementing PT Asia Forestama Raya's CSR towards the empowerment of the community economy in Limbungan Village from the company side is that the financial condition of PT Asia Forestama Raya is currently in an unstable state so that it has been three years since there has been no implementation of community economic empowerment programs. Meanwhile, the obstacle in implementing PT Asia Forestama Raya's CSR on community economic empowerment in Limbungan Village from the community side is the lack of public knowledge regarding Riau Province Regional Regulation Number 6 of 2012 concerning Corporate Social Responsibility in Riau Province. 
The CSR program is actually not only beneficial for the community, but also useful for shaping the company's image if it is packaged with the right publications [17]. In addition, the benefits of the CSR program for companies are as follows [18]:

1. Maintain and boost the company's reputation and brand image.

2. Obtain a license to operate socially.

3. Reducing the company's business risk.

4. Widen access to resources for business operations.

5. Opening up a wider market opportunity.

6. Reducing costs.

7. Improve relations with stakeholders.

8. Improve relations with regulators.

9. Increase employee morale and productivity.

In order to maintain the effectiveness of the implementation of Riau Province Regional Regulation Number 6 of 2012 concerning Corporate Social Responsibility in Riau Province, intensive supervision from the government is required [19].

Efforts can be made by the people of Limbungan Village if PT Asia Forestama Raya doesn't carry out a community economic empowerment program, namely conveying its aspirations to Commission IV of DPRD Pekanbaru City so that the company is recommended to receive strict sanctions from the Pekanbaru City Government.

With regard to CSR, companies are grouped internationally into four categories as follows [20]:

1. Black Company

The companies, including the Balck Company, in carrying out their business activities prioritize business interests to seek maximum profit without paying attention to the condition of the community and the surrounding environment.

2. Red Company

The companies, including the Red Company, have started to carry out corporate social responsibility to the people who live in the vicinity of the company, but corporate social responsibility is considered an expense that can reduce company profits.

3. Blue Company

The company, including the Blue Company, carries out corporate social responsibility for the people who live around the company's location with the aim of maintaining good relations between the company and the community as an investment.

4. Green Company

Companies, including the Green Company, place corporate social responsibility as a part of its core business because corporate social responsibility is a mandatory requirement to carry out in carrying out its business activities.

Based on Article 32 of Riau Province Regional Regulation Number 6 of 2012 concerning Corporate Social Responsibility in Riau Province, it is stated that if PT Asia Forestama Raya doesn't carry out CSR towards community economic empowerment, the company can be subject to administrative sanctions in the form of a written warning from the Pekanbaru City Government and restrictions the company's business activities, freezing the company's business license, to revoking the company's business license.

\section{Conclusion}

PT Asia Forestama Raya is a forest product processing factory for the wood industry's raw materials. Based on Article 74 Paragraph (1) of Law Number 40 of 2007 concerning Limited Liability Companies, it is stipulated that companies that carry out their business activities in the natural resources sector and / or fields related to natural resources are required to implement CSR. In Article 10 of Riau Province Regional Regulation Number 6 of 2012 concerning Corporate Social Responsibility in Riau Province, it is stated that CSR programs can take the form of community economic empowerment. During the Covid-19 pandemic, the public really expected a real contribution from PT Asia Forestama Raya. PT Asia Forestama Raya's obstacle in implementing community economic empowerment in Limbungan Village is that the financial condition of PT Asia 
Forestama Raya is currently in an unstable state. Efforts that can be made by the people of Limbungan Village if PT Asia Forestama Raya does not carry out a CSR program are to convey their aspirations to Commission IV of DPRD Pekanbaru City. Based on Article 32 of Riau Province Regional Regulation Number 6 of 2012 concerning Corporate Social Responsibility in Riau Province, it is stated that if PT Asia Forestama Raya does not carry out CSR towards empowering the community's economy, the company can be subject to administrative sanctions by the Pekanbaru City Government.

\section{References}

[1] R. Khairandy, Limited Liability Company: Doctrine, Legislation, and Jurisprudence. Yogyakarta: Kreasi Total Media, 2009.

[2] A. S. Utama and Rizana, "Implementation of Corporate Social Responsibility in the Framework of Optimizing Environmental Preservation" Litigasi Journal, vol. 19, no. 2, pp. 127-147, 2018.

[3] Fahmi, Shift in Corporate Social Responsibility:From Moral Liability to Legal Liability. Yogyakarta: FH UII Press, 2015.

[4] A. S. Utama, and Rizana, "Law Enforcement on the Implementation of Corporate Social Responsibility in Rumbai District, Pekanbaru" Equitable Journal, vol. 3,no. 1, pp. 1-11, 2018.

[5] A. S. Utama, "The Implementation of Corporate Social Responsibility (CSR) PT Riau Crumb Rubber Factory to the Community of Sri Meranti Village in Pekanbaru" Proceeding of International Conference Icon-ITSD, vol. 175, pp. 1-6, 2018.

[6] Fahrial, A. S. Utama and S. Dewi, "Utilization of Corporate Social Responsibility (CSR) for Village Economic Development" Wawasan Yuridika Journal, vol. 3 no. 2, pp. 259-272, 2019.

[7] Hasnati, S. Dewi and A. S. Utama, "Corporate CSR Program: Alternative Village Community Economic Empowerment" Comsep Journal, vol. 1,no. 1, pp. 25-31, 2020.

[8] Suhendro and A.S. Utama, "Implementation of Corporate Social Responsibility by PT Asia Forestama Raya in Rumbai Pesisir District of Pekanbaru City Based on Regional Regulation of Riau Province 6 of 2012" Russian Journal of Agricultural and Socio-Economic Sciences, vol. 9, no. 93, pp. 274-284, 2019.

[9] S. Soekanto, Introduction to Legal Research. Jakarta: UI Press, 2007.

[10] A. S. Utama, "Problems in the Implementation of Social Responsibility for Forestry and Plantation Companies in Pelalawan Regency, Riau Province" Supremasi Hukum Journal, Vol. 1 No. 2, Pp. 67-80, 2018.

[11] Suhendro, A.S. Utama, and A.P. Susanty, "Implementation of PT Asia Forestama Raya's CSR towards Improving the Community's Economy Based on Riau Province Regional Regulation Number 6 of 2012" Ensiklopedia Social Review Journal, vol. 1, no. 2, pp. 140-144, 2019.

[12] A. S. Utama, and Rizana, "Implementation of PT Riau Crumb Rubber Factory Corporate Social Responsibility for the Sri Meranti Village Community in Pekanbaru City" Novelty Journal, vol. 8,no. 2, pp. 173-186, 2017.

[13] A. S. Utama, Rizana and T. A. Putra, "PT Asia Forestama Raya's Corporate Social Responsibility in Pekanbaru City and its Law Enforcement" Pagaruyuang Law Journal, vol. 2, no. 2, pp. 148-162, 2019.

[14] A.S. Utama, "Implementation of PT Riau Andalan Pulp \& Paper Corporate Social Responsibility for Communities in Pelalawan Regency" Selat Journal, vol. 5, no. 2, pp. 123133, 2018.

[15] Fahrial, R. Fatriani and A. S. Utama, "Utilization of Corporate Social and Environmental Responsibility to Improve Community Economy in Pekanbaru City" Proceeding of International Conference ICE-Tech, vol. 469, pp. 1-5, 2020.

[16] A.S. Utama, "Utilization of the Company's CSR Program for Economic Empowerment of the People of Pelalawan Regency during the Covid-19 Pandemic" Proceeding of National Seminar on Community Empowerment, vol. 2, pp. 77-83, 2020.

[17] Hasnati and A. S. Utama, "Implementation of Corporate Social Responsibility (CSR) by Forestry and Plantation Companies in Pelalawan Regency, Riau Province, Indonesia" Journal of Law and Political Sciences, vol. 25, no. 4, pp. 309-332, 2020.

[18] Suparman, "Corporate Social Responsibility:Forms of Corporate Social Responsibility and Concern for the Community", Interaksi Journal, Vol. 2, no. 2, pp. 69-81, 2013. 
Fahrial, Andrew Shandy Utama.

Implementation of PT Asia Forestama Raya's CSR for Community Economic Empowerment during the Covid-19 Pandemic.

International Journal of Law and Public Policy, vol. 3, no. 1, pp. 60-66, March 2021. DOI: 10.36079/lamintang.ijlapp-0301.206

[19] A. S. Utama, and Rizana, "Rumbai District Community Legal Efforts in Fulfilling Community Rights through Corporate Social Responsibility (CSR) Programs" Melayunesia Law Journal, vol. 2, no. 1, pp. 79-93, 2018.

[20] A. S. Utama, "Implementation of Corporate Social and Environmental Responsibility Based on Law Number 40 of 2007 to Improve Community Welfare in Rumbai Pesisir District, Pekanbaru City" Cendekia Hukum Journal, vol. 4, no. 1, pp. 26-36, 2018. 